\title{
Efficiency Research of Chinese Commercial Banks Based on Super-Efficiency DEA Method
}

\author{
Xiaojuan Fan \\ School of Economics, Jinan University, Guangzhou, China \\ Email: f902366@163.com
}

Received 6 April 2016; accepted 21 April 2016; published 26 April 2016

Copyright (C) 2016 by author and Scientific Research Publishing Inc.

This work is licensed under the Creative Commons Attribution International License (CC BY).

http://creativecommons.org/licenses/by/4.0/

(c) (i) Open Access

\begin{abstract}
This paper tries to analyze Chinese three types of bank's efficiency changes and differences, after the financial crisis, through the integrated use of DEA and super efficiency DEA method. The results show that: the efficiency of Chinese commercial Banks in general is on the rise, the comprehensive technical efficiency growth stems mainly from scale efficiency improvement, pure technical efficiency is stagnant, and scale efficiency presents convergence among all kinds of banks, while the technical level is the core strength of banks' current and future competition. Stateowned banks with the technology competitive advantage and scale efficiency improved, began to catch up with other banks, reversed the operational inefficiency; City commercial banks due to the system advantage were more easily to be in the efficient production frontier surface.
\end{abstract}

\section{Keywords}

DEA, Super-Efficiency, Commercial Banks, Efficiency

\section{Introduction}

After the 2008 financial crisis, China's real economic growth slowed, and China's commercial banks are facing fierce competition both from internal and external situations, as more and more foreign banks enter China and non-financial institutions grab the market share of the domestic banks by means of the Internet financial innovation. In this context, we will naturally raise the following issues: What happened to the overall efficiency of our banking with China's real economy affected by financial crisis? Are there differences in efficiency and relative competitive advantages between all types of bank? Are state-owned banks still operating in efficiently? 
On the one hand, efficiency is a measure of the effectiveness of the indicators of commercial banks' operating activities. From the microscopic point of view, it reflects the degree of a bank utilization of human, capital and other resources, while the overall efficiency of the banking also reflects economies of capital allocation capabilities from the macro perspective. On the other hand, the study of this paper on China's bank efficiency can obtain the current status of overall efficiency and efficiency changes of China's commercial banks, which can determine whether the efficiency variance of various types is significant, whether the nature of property rights decide the inefficiency of China's state-owned bank. To sum up, this article still has great theoretical and practical significance on efficiency study of commercial bank.

This paper attempts to make differences in two aspects on the basis of the existing literature: First, enlarge the sample, including 60 commercial banks in China over the period 2008 2014; Second, with the integrated use of DEA and super-efficiency DEA method, this paper may provide some useful ideas for deepening characteristic reforms between different types of banks, under an identical framework for efficiency and super efficiency. Given the difficulty to obtain other variable data for sample bank, the limitation of this paper is no further empirical test for what kinds of factors cause the differences among banks.

\section{Literature Review}

Foreign scholars have begun to study the efficiency difference among banks, after Sherman and Gold (1985) for the first time applied the DEA in efficiency evaluation between the branches of a bank, the representative scholars like Berger and Humphrey (1993), Isik and Hassan (2002), Ekenl and Kale (2011) [1]-[4]. China's scholars like Fang Chunyang et al. (2004), Zhu Nan et al. (2004), Zheng Lujun et al. (2005), Guo Yan (2005), Zhao Yongle and Wang Juntan (2008) [5]-[9] launched a wealth of research in efficiency differences of commercial banks based the mainstream of DEA method, a few scholars such as Wang Cong and Tan Zhengxun (2007), Liu Mengfei et al. (2015) use SFA(stochastic frontier analysis) approach to analyze the efficiency of commercial banks [10] [11].

The general DEA model can only classify decision-making unit into two types of effective and ineffective and generally there are many efficiency scores of effective decision-making unit that is 1 , which is indistinguishable and compared. To overcome this defect, scholars use improved methods of super-efficiency DEA to achieve effective bank reordering. Zhao Xiang (2010) Measured 40 branches efficiency of a commercial based on Superefficiency DEA model. Wu Kelin (2012) calculated bank overall efficiency by Super-efficiency DEA, but the sample is only limited to 20 banks of 2009-2010 years, the selected variables only limited to the bank's internal characteristic variables without considering industry factors and the macroeconomic context [12] [13]. Li Jinpei et al. (2014) used the SBM (Slacks-based model) super efficiency model to study the impact of monetary policy on China commercial bank of risk-exposures ,but the defect of the research is that the sample only have 11 banks and does not include the Agricultural Bank of China which accounts for a larger market share [14]. Nguyen Khac Minh et al. (2013) used the SBM super efficiency model to compare the efficiency performance of Vietnam's 32 commercial banks [15].

\section{The Model and the Data}

\subsection{DEA Model}

DEA is a non-parametric efficiency assessment methodology for more output with multi-input, which uses linear programming methods to construct effective frontier of containing several decision-making unit (DMU) and uses distance between the current production point of each decision unit and effective frontier as the level of efficiency evaluation index. If the cacyulation of the efficiency is 1 , the DMU is on the effective frontier, which is effective; If it locate between 0 and 1 , the DMU is invalid and then the distance from the effective frontier is the efficiency loss.

In this paper, DEA model of China's commercial banks efficiency evaluation is as follows:

Define $\theta_{j}=\frac{u^{\mathrm{T}} Y_{j}}{v^{\mathrm{T}} X_{j}}=\frac{\sum_{r=1}^{s} u_{r y_{r j}}}{\sum_{i=1}^{m} v_{i} x_{i j}}(j=1, \cdots, n)$ as the $j$ commercial bank's efficiency rating index of $D M U_{j}$.

Then under the hypothesis of constant returns to scale, the CCR model is: 


$$
\left\{\begin{array}{l}
\text { Maximize } \theta_{o}=\frac{\sum_{r=1}^{s} u_{r} y_{r o}}{\sum_{i=1}^{m} v_{i} x_{i o}} \\
\text { s.t. } \frac{\sum_{r=1}^{s} u_{r} y_{r j}}{\sum_{i=1}^{m} v_{i} x_{i j}} \leq 1
\end{array}\right.
$$

Among them, $j=1, \cdots, n ; \quad u_{r} \geq 0 ; v_{i} \geq 0 ; \forall r, i$

Among them, $x_{i j}, y_{r j}$ represent the $j$-bank's the input of $i$ and output of $r$ respectively. Each bank has as much as s output indicators and $\mathrm{m}$ input indicators. Input vector and output vector are as follows:

$X_{j}\left(x_{1 j}, x_{2 j}, \cdots, x_{m j}\right)^{\mathrm{T}}>0, Y_{j}\left(y_{1 j}, y_{2 j}, \cdots, y_{s j}\right)^{\mathrm{T}}>0,(j=1, \cdots, n)$, Input weight vector and output weight vector are as follows: $v=\left(v_{1}, v_{2}, \cdots, v_{m}\right)^{\mathrm{T}}, u=\left(u_{1}, u_{2}, \cdots, u_{s}\right)^{\mathrm{T}}$. To maximize $\theta_{o}$, Charne and Cooper (1963) propose Charnes-Cooper transformation of fractional programming, which obtain the following linear programming model:

$$
\left\{\begin{array}{l}
\text { Minimize } \theta_{o} \\
\text { s.t. } \sum_{j=1}^{n} x_{i j} \lambda_{j} \leq \theta x_{i o}(i=1, \cdots, m), \sum_{j=1}^{n} y_{r j} \lambda_{j} \geq y_{r o}
\end{array}\right.
$$

among them $r=1, \cdots, s ; \quad \lambda_{j} \geq 0, \quad j=1, \cdots, n$

The above model is based on the sample banks of the "best" commercial banks as reference objects, so the resulting efficiency are relatively efficient and less than or equal to 1 . On the basis of CCR model, we add a convexity assumption: $\sum_{j=1}^{n} \lambda_{j}=1$, assuming the returns to scale is variable, then we get the BCC model. BCC model can decompose comprehensive technical efficiency into pure technical efficiency and scale efficiency. Among them, the pure technical efficiency measures the gap between the decision-making unit and the production frontier under the hypothesis of variable returns to scale. Scale efficiency measures the gap between two production frontiers under the hypothesis of variable returns to scale and constant returns to scale.

\subsection{Super-Efficiency DEA Model}

When use the CCR model , it often occurs that multiple DMU efficiency value is 1, therefore, Andersen and Petersen (1993) proposed super-efficiency method which cause the DMU to be evaluated excluded from the efficiency frontier, then construct new efficiency frontier with the remaining DMU. Because removed DMU is not included by the efficiency of the border, the new efficiency value will be greater than 1 . In order to achieve there-evaluation of effective DMU, On the basis of Formula (2), Super-efficiency DEA model can be modified

$$
\left\{\begin{array}{l}
\text { Minimize } \theta_{o} \\
\text { s.t. } \sum_{\substack{r=1 \\
j \neq k}}^{n} x_{i j} \lambda_{j} \leq \theta x_{i o}(i=1, \cdots, m), \sum_{\substack{r=1 \\
j \neq k}}^{n} y_{r j} \lambda_{j} \geq y_{r o}
\end{array}\right.
$$

Among them $r=1, \cdots, s ; \quad \lambda_{j} \geq 0, j=1, \cdots, k-1, k+1, \cdots, n$.

\subsection{Data and the Specification of Variables}

This paper's data include five major state-owned commercial banks, 12 national joint-stock commercial banks and 43 city commercial banks data between the 2008 and 2014 in China. Part of the data are from the Bankscope database, part of the data from the wind, the missing data from the Bank consolidated financial statement, which comprise the consolidated financial statement of the Bank and its subsidiaries ${ }^{1}$.

\footnotetext{
${ }^{1}$ BankScope is a kind of banking information database, opened up by BvD (Bureau van DrDijk Electronic Publishing: world famous professional empirical database providers of finance and economics) and banking authority agencies Fitch Ratings; Wind means wind info (China's leading financial data, software and information service enterprise, whose headquarters is located in Shanghai Lujiazui financial center) The data between 2008 and 2012 mainly are from Bank scope database, several banks like Ping An Bank and Ever growing Bank, whose data between 2008 and 2009 are from their consolidated financial statement, and Industrial Bank, Ever bright Bank, whose data in 2008 are from their consolidated financial statement.
} 
The variables of inputs and outputs are in reference of Yonghong Jiang and Weijie Jiang (2014) which select interest expenses, operating and administrative expenses, total deposits as input indicators, interest income, noninterest income and total loans as output indicators in accordance with the practice of "intermediation approach" [14]. The non-interest income $=$ fees and commission income + investment income +income from change in fair value + changes in foreign exchange gains + other operating income. The variable descriptive statistics are in Table 1.

\section{The Empirical Results and Analysis}

Empirical analysis of ideas of this paper is as follow: Firstly, analyzing the change features in the overall efficiency of commercial banks based on the general characteristics of DEA results; Secondly, comparing efficiency variance between three banks based on Super Efficiency DEA results; Finally, analyzing the relative efficiency advantage of three banks according to efficiency decomposed. It should be noted that Efficiency Measurement results in this article are based on input-oriented model.

\subsection{The Overall Efficiency Analysis of Commercial Banks}

The DEA results sorted out are shown in Table 2 and Figure 1, we find that the pure technical efficiency of Chinese commercial banks are less volatile, the average calendar year located in $[0.97,0.98]$ interval; scale effi-

Table 1. Descriptive statistics for each indicator data from 2008 to 2014Unit: 100 million.

\begin{tabular}{|c|c|c|c|c|c|c|c|}
\hline & & \multicolumn{3}{|c|}{ Output indicators } & \multicolumn{3}{|c|}{ Input indicators } \\
\hline & & $\begin{array}{l}\text { Interest } \\
\text { income }\end{array}$ & $\begin{array}{l}\text { Non-interest } \\
\text { income }\end{array}$ & Total loans & $\begin{array}{l}\text { Interest } \\
\text { expense }\end{array}$ & $\begin{array}{l}\text { Operating and } \\
\text { administrative } \\
\text { expenses }\end{array}$ & $\begin{array}{c}\text { Total } \\
\text { deposits }\end{array}$ \\
\hline \multirow{4}{*}{$\begin{array}{l}\text { State-owned } \\
\text { banks (5) }\end{array}$} & Means & 4388.89 & 761.66 & $57,111.13$ & 1792.61 & 1085.30 & $86,621.59$ \\
\hline & Standard deviation & 1941.12 & 430.59 & $25,279.57$ & 811.40 & 450.11 & $36,452.85$ \\
\hline & Min & 1166.39 & 113.31 & $11,044.90$ & 500.75 & 257.10 & $18,658.15$ \\
\hline & Max & 8498.79 & 1795.51 & $110,263.30$ & 3563.57 & 1799.92 & $155,566.00$ \\
\hline \multirow{4}{*}{$\begin{array}{c}\text { Joint-stock } \\
\text { commercial } \\
\text { banks (12) }\end{array}$} & Means & 756.00 & 95.48 & 8208.10 & 377.22 & 158.51 & $11,279.07$ \\
\hline & Standard deviation & 590.20 & 111.33 & 6067.66 & 309.81 & 119.02 & 8137.44 \\
\hline & Min & 24.00 & 0.42 & 347.49 & 14.09 & 7.75 & 486.53 \\
\hline & Max & 2228.34 & 577.10 & 25,139.19 & 1238.54 & 506.56 & $33,044.38$ \\
\hline \multirow{4}{*}{$\begin{array}{c}\text { City } \\
\text { commercial banks } \\
\text { (43) }\end{array}$} & Means & 66.44 & 6.32 & 659.99 & 31.92 & 13.32 & 1072.53 \\
\hline & Standard deviation & 87.14 & 8.92 & 852.11 & 47.93 & 13.85 & 1273.24 \\
\hline & Min & 3.04 & 0.01 & 20.19 & 0.85 & 1.12 & 75.95 \\
\hline & Max & 732.55 & 59.84 & 6752.88 & 419.70 & 90.91 & 9228.13 \\
\hline
\end{tabular}

Note: The data sorted out by the author.

Table 2. The annual average efficiency for China's banking industry.

\begin{tabular}{cccccccccc}
\hline Year & 2008 & 2009 & 2010 & 2011 & 2012 & 2013 & 2014 & Annual average \\
CTE & 0.938 & 0.937 & 0.943 & 0.940 & 0.956 & 0.960 & 0.974 \\
PTE & 0.976 & 0.974 & 0.973 & 0.971 & 0.972 & 0.972 & 0.980 \\
SE & 0.961 & 0.962 & 0.969 & 0.967 & 0.984 & 0.989 & 0.994 \\
$\begin{array}{c}\text { The number of } \\
\text { effective banks }\end{array}$ & 18 & 20 & 18 & 20 & 25 & 27 & 28 \\
\hline
\end{tabular}




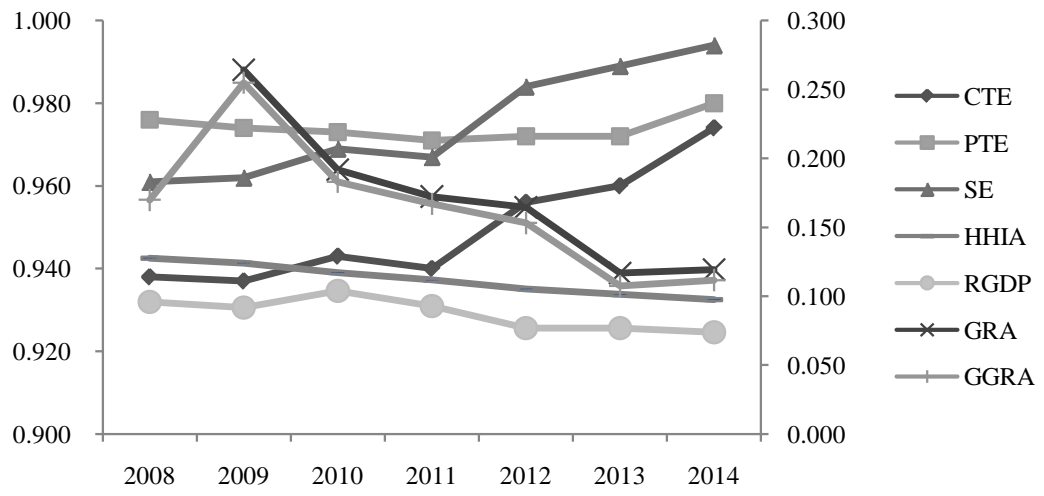

Figure 1. The annual average efficiency for China's banking industry. Note. The data of RGDP (the real growth of China's GDP), GGRA (gross growth rate of assets for the banking industry) comes from wind, GRA(growth rate of assets for the sample banks), HHIA (estimate based on the banks' assets) calculated by author. In addition, HHI index is required to multiply 1000 when in practice use, if it is greater than 1800, the market is considered highly concentrated, if it is between 1000 and 1800 , the market is moderately concentrated, if it is less than 1000, the market is considered mild concentrated.

ciency is fluctuating upward trend, and start higher than pure technical efficiency in 2012; comprehensive technical efficiency present changes feature in consistent with scale efficiency, and the performance of its average increase from 0.938 in 2008 to 0.974 in 2014, effective banks from the number of 18 the number of 28, nearly half of the sample banks already in the efficient production frontier by 2014; it should be noted that the level of Comprehensive technical efficiency is always less than the scale efficiency and the pure technical efficiency, which is because comprehensive scale efficiency is equal to the product of scale efficiency and pure technical efficiency, as the scale efficiency and pure technical efficiency is not always less than 1.

As described above, a substantial increase in the size efficiency but stagnating pure technical efficiency in Chinese banking sector need our focus. Based on this, this paper attempts to analyze the external forces of enhancing Chinese banks' efficiency from the perspective of macroeconomic environment and market structure. The existing literature usually use absolute size of banking assets to measure the size-expansion in the analysis of bank scale efficiency, however, this paper uses bank assets growth indicators to measure; Market structure indicators refer the practices of Xin Ye et al. (2001) [16], which select HHI index of bank assets to measure; macroeconomic environment select growth rate of real GDP to measure. The results are shown in Figure 1.

From the rate of growth of bank assets, Asset growth rate of sample bank present a parallel growth trend with rate of total asset growth, which can be explained to some extent that the sample is representative. But after high growth rate of 25.49 percent in the total assets of banking sector achieved in 2009, it began to decline year by year, reaching $10.75 \%$ of the lowest level of growth in 2013. This reason may as follow: first, along with China's overall economic strengthening, the absolute size of the bank's total assets remained the trend of expansion in the post-crisis year, especially government's four trillion bailout loans which lead to social demand expansion in the 2008, coupled with loose monetary policy which cause ample liquidity in the banking system, then financial institutions expand credit and the growth rate of bank assets reached a peak in 2009 due to rapid growth of loans; The second, Affected by the global liquidity easing and remaining large Chinese balance of payments surplus in 2010, bank liquidity supply sided, domestic inflation pressured, real economic growth declined, and China's real GDP growth rate hit a new 24-year low by 2014. With the macro-economic slowdown, growth in social demand for loans decreased in 2010, What's more, with the China tightening monetary, revitalizing the stock and good use of incremental, Loan growth rate slowed, which cause the expansion rate of bank assets scale declining.

From the aspect of market structure, HHIA declines by year and it is below 1000 in 2014, which indicates the market structure of the banking industry in china is in moderate concentration while the concentration continues to decrease. As the competition of the banking industry is becoming more and more serious, and the expansions of the banks are limited, the asset's growth rate of the industry is facing a fall.

In conclusion, on the one side, the banking industry of china continues to expand in an absolute scale when the country's economy is rising, which makes it incorrect to use the absolute value of assets to estimate the expansion scale of the banking industry. On the other hand, as the increase of the real economy is slowed down and the competition of the industry becomes more and more serious, the speed that the banks expand their scales 
is force to be decrease. From 2009, the asset’s growth rate continues to decease which may means the banking industry of china is started to adjust the development strategy. The time of "Scale expansion" is over, which, however, is the external force that drive the scale efficiency of the banking to rise greatly in the sample period.

But the pure technical efficiency is basically stagnant and it has changed until 2014. It means now the efficiency loss of the banks mainly comes from the inefficiency of pure technique. Besides, to improve efficiency, we should focus on technical aspects like improving the internal structure of banks and paying attention to the construction of information technology. Also, we should learn advanced management experience from foreign banks, promote the development strategy of the banking industry (globalization and diversification) and speed up to assort relevant ability of management for the totally expanding banking industry.

\subsection{The Comparison Based on the Super-Efficiency DEA}

Taking into account the DEA method can't distinguish variance among all the effective banks, we use super-efficiency DEA to analyze efficiency discrepancy of three kinds of banks (here is state-owned commercial banks, national joint-stock commercial banks, and city commercial banks). The results shown in Figure 2.

According to the concentration of distribution of effective banks, the city commercial banks over the years have more than $25 \%$ located in the production frontier, significantly higher than joint-stock banks and stateowned banks in absolute numbers. Effective banks accounted for basically $25 \%$ for joint-stock banks, while the number of effective state-owned banks began to grow steadily after 2011. It shows that, compared with large and medium sized banks such as the joint-stock or state-owned banks or other national banks, city commercial banks easier to achieve the least input under the same level of output, due to a close combination with local economy, relatively flexible decision-making, motivation and employment mechanism, and "small boat U-turn" institutional advantages.

From the point of view of the bank's SDEA changing trends, the state-owned banks' efficiency improved most significantly, especially in 2013, there were four state-owned banks achieved to be effective, which may means state-owned banks begin to reverse the long-term operation inefficient situation, showing catching up effect, and a series of reform measures are working for the large state-owned commercial banks ,such as shareholding reform, comprehensive operation ,internationalization strategy and other measures.

From the distribution range of normal and abnormal SDEA values, the city commercial banks suffered the worst degree of concentration, followed by joint-stock banks. The city commercial banks have the longest tail and a longest rectangular box-section among the three types of banks, meanwhile, the city commercial banks have the lowest lower edge as well as the highest upper edge. Besides, the state-owned banks' dispersion is minimized except for the presence of unusually small value between 2009 and 2013. These show that, although city commercial banks easier to run business effectively, and to realize "catching up" with the advantage of characteristic and differential of business strategy and closely connected with domestic market, they prone to be "polarized", which leads to effective banks with much bigger DEA values, while non-effective banks with much smaller DEA values. As the consequence, the policy orient to the city commercial banks should focus on the differentiation when compared with state-owned banks and joint-stock banks.

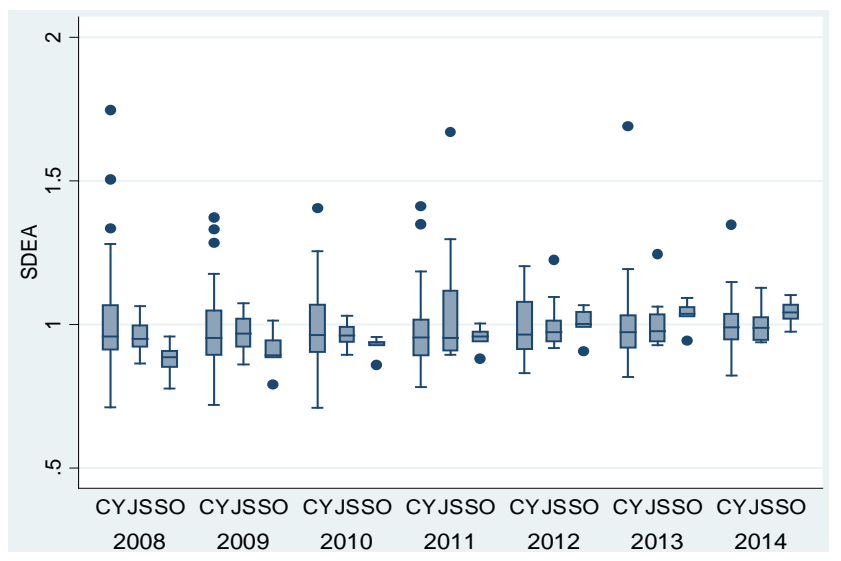

Figure 2. The distribution of the SDEA of commercial banks. Note: CY refers to the city commercial banks; JS refers to the joint-stock commercial banks; SO refers to the state-owned commercial banks. SDEA means Super-efficiency DEA. 


\subsection{Relative Efficiency Advantage of Various Banks}

Here, we try to find the inner motive power of the above characteristics of banks' efficiency and relative efficiency advantages of various banks with the help of decomposition of technical efficiency. The results are shown in Figure 3 and Figure 4.

First, the state-owned banks, on the one hand, performed best in PTE, even five of them all have realized pure technology effectively after the year 2010. It indicates that the five state-owned banks have an absolute advantage in acceptance and application of new technology; On the other hand, the state-owned banks have the worst performance in SE by 2011, but after the year 2012 began to catch up with other banks, and eventually four of them reach in scale in 2013, 2014. In conclusion, the SDEA changing trends above are mainly caused by the change of SE for state-owned banks, whose long-term operating inefficiency situation mainly derived from diseconomies of scale.

Second, the joint-stock commercial banks' PTE is lower than state-owned banks in both sides of the median and distribution of the normal range, and the absolute volume of banks realized pure technology effectively is

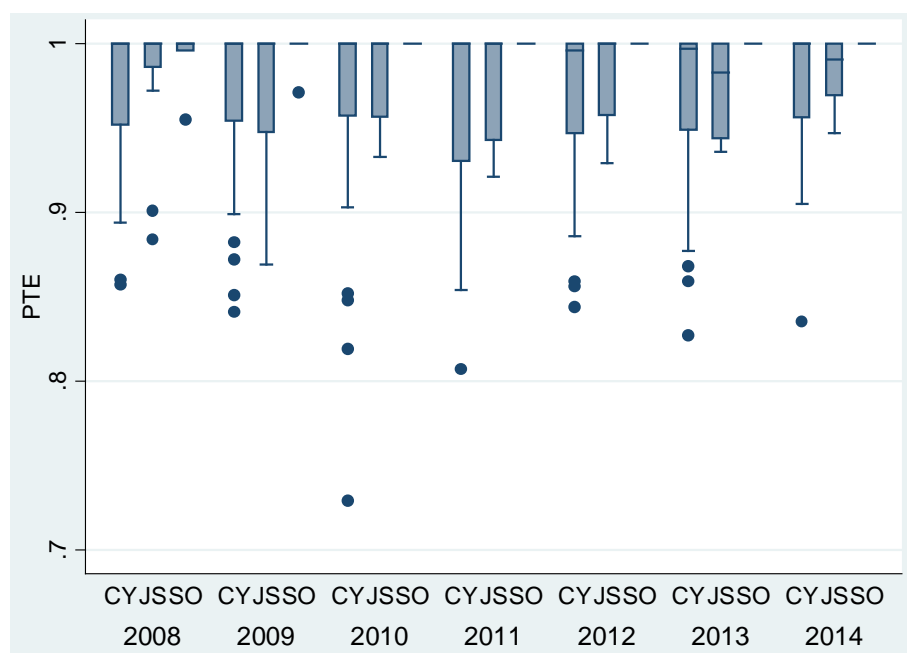

Figure 3. The distribution of the PTE of commercial banks. Note: PTE, pure technical efficiency; SE, scale efficiency.CY refers to the city commercial banks; JS refers to the joint-stock commercial banks; SO refers to the state-owned commercial banks.

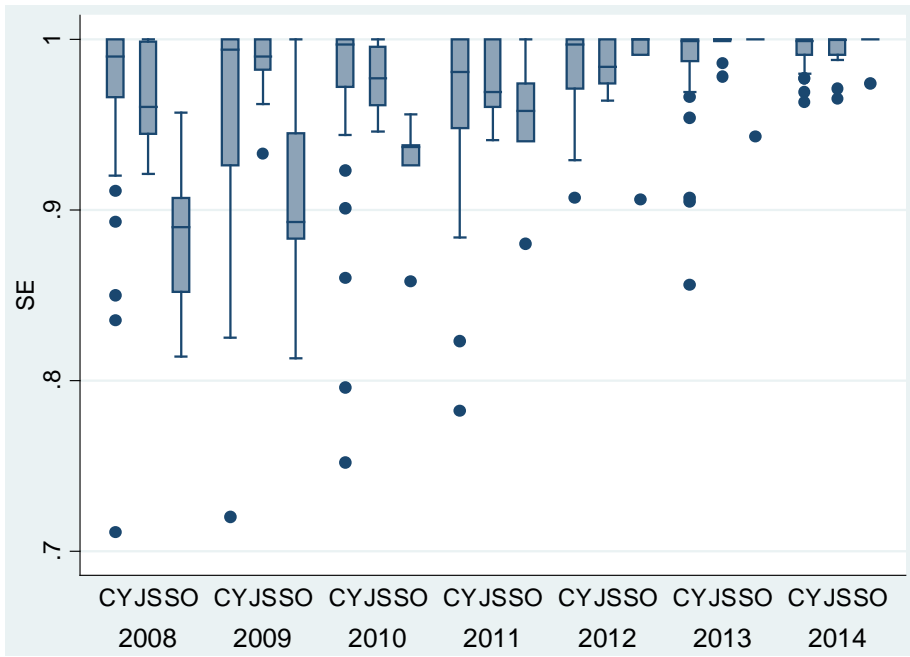

Figure 4. The distribution of the SE of commercial banks. Note: PTE, pure technical efficiency; SE, scale efficiency.CY refers to the city commercial banks; JS refers to the joint-stock commercial banks; SO refers to the state-owned commercial banks. 
also less than the city commercial banks, especially in 2009, 2013, 2014; As for SE, the joint-stock commercial banks perform better than that of state-owned banks by 2012, while inferior to city commercial banks in both sides of the median and the upper quartile.

Third, the city commercial banks have a relative advantage in terms of SE. However, its advantage is gradually threatened for the scale efficiency gap between banks is being smaller; When compared with state-owned banks, the relative advantage in PTE is not obvious, but the absolute volume of banks realized pure technology effectively is still higher than that of state-owned banks and joint-stock banks; On the other side, the PTE difference between city commercial banks is much bigger, shows that its efficiency difference mainly caused by the difference of technical level.

\section{Conclusion}

In this paper, through the integrated use of DEA and super efficiency DEA method, we find: First, the efficiency of Chinese commercial Banks in general is on the rise after the crisis, the comprehensive TE growth stems mainly from SE improvement, while PTE is at a substantially standstill; Second, city commercial banks are much easier to be located in effective frontier, while they are more prone to be "polarized", and the state-owned banks' efficiency improved most significantly after the year 2012; Third, there is a relative advantage in technical level for state-owned banks, while city commercial banks have a relative advantage in terms of SE and joint-stock banks have no obvious advantage in either PTE or SE; Fourth, the SE presents convergence among all kinds of banks, which means technique is going to be the core strength in banks' current and future competition.

\section{References}

[1] Sherman, H.D. and Gold, F. (1985) Bank Branch Operating Efficiency: Evaluation with Data Envelopment Analysis. Journal of Banking and Finance, 9, 297-315. http://dx.doi.org/10.1016/0378-4266(85)90025-1

[2] Berger, A.N. and Humphrey, D.B. (1993) Bank Efficiency Derived from the Profit Function. Journal of Banking and Finance, 17, 317-345. http://dx.doi.org/10.1016/0378-4266(93)90035-C

[3] Isik, I. and Hassan, M.K. (2002) Technical, Scale and Allocative Efficiencies of Turkish Banking Industry. Journal of Banking \& Finance, 26, 719-766.

[4] Ekenl, M.H. and Kale, S. (2011) Measuring Bank Branch Performance Using Data Envelopment Analysis (DEA): The Case of Turkish Bank Branches. African Journal of Business Management, 5, 889-901.

[5] Fang, C.Y., Sun, W., Wang, Z. and Wang, H.R. (2004) The Measuring of Efficiency and Empirical Test of the Behavior Characteristics for the state-Owned Commercial Banks. The Journal of Quantitative \& Technical Economics, No. 7, 51-58.

[6] Zhu, N., Zhuo, X. and Dong, Y. (2004) The Empirical Analyses on the Efficiency and Reform Strategy of StateOwned Commercial Banks in China. Management World, No. 2, 18-26.

[7] Zheng, L.J. and Cao, T.Q. (2005) An Empirical Analysis of Commercial Banks' Efficiency and Its Influencing Factors in Our Country. Journal of Financial Research, No. 1, 91-101.

[8] Guo, Y. (2005) A Theoretical Probe and Empirical Test of Determinants to Our Country’s Commercial Banks’ Efficiency. Journal of Financial Research, No. 2, 115-123.

[9] Zhao, Y.L. and Wang, J.T. (2008) Interpretation of Model Results of Commercial Banks Efficiency, Impact Factors and the Ability to Model. Journal of Financial Research, No. 3, 58-69.

[10] Wang, C. and Tan, Z.X. (2007) Research on Business Banks in Structure. Economic Research Journal, No. 7, $110-123$.

[11] Liu, M.F., Chen, X.M. and Wu, X. (2015) Comparative Study of Technical Efficiency and Productivity of Chinese and Foreign Bank. Journal of Industrial Engineering and Engineering Management, No. 1, 128-134.

[12] Zhao, X. (2010) Bank Branches’ Efficiency Measure and Influence Factors Analysis_Empirical Research Based on Super Efficiency DEA and Tobit Model. Economic Science, No. 1, 85-96.

[13] Wu, K.L. (2012) Our Country’s commercial Bank Efficiency Research-Based on Super Efficiency DEA Model. Journal of Zhongnan University of Economics and Law, No. 2, 65-72.

[14] Li, J.P., Lv, D.H. and Huang, Y.X. (2014) Monetary Policy, Risk-Taking and Bank’s Efficiency-The Empirical Research Based on the Panel Data of Chinese Commercial Banks. Journal of Guizhou College of Finance and Economics, No. 6, 48-56. 
[15] Minh, N.K., Long, G.T. and Hung, N.V. (2013) Effiency and Super-Efficiency of Commercial Banks in Vietnam: Performances and Determinants. Asia-Pacific Journal of Operational Research, 30, 1250047.

[16] Ye, X., Guo, J.W. and Feng, Z.X. (2001) Monopoly to Competition: The Changes of Market Structure of the Chinese Commercial Banks. Journal of Financial Research, No. 11, 79-85. 